Marquette University

e-Publications@Marquette

Social and Cultural Sciences Faculty Research and

Publications

Social and Cultural Sciences, Department of

$4-1-2018$

Review of Race Scholarship and the War on Terror

Louise Cainkar

Marquette University, Louise.Cainkar@mu.edu

Saher Selod

Simmons College

Accepted version. Sociology of Race and Ethnicity, Vol. 4, No. 2 (April 1, 2018): 165-177. DOI. (C) 2018 by American Sociological Association. Used with permission. 
Marquette University

e-Publications@Marquette

\section{Social and Cultural Sciences Faculty Research and Publications/Department of Social and Cultural Sciences}

This paper is NOT THE PUBLISHED VERSION; but the author's final, peer-reviewed manuscript.

The published version may be accessed by following the link in the citation below.

Sociology of Race and Ethnicity, Vol. 4, No. 2 (2018): 165-177. DOI. This article is (C SAGE Publications and permission has been granted for this version to appear in e-

Publications@Marquette. SAGE Publications does not grant permission for this article to be further copied/distributed or hosted elsewhere without the express permission from SAGE Publications.

\section{Contents}

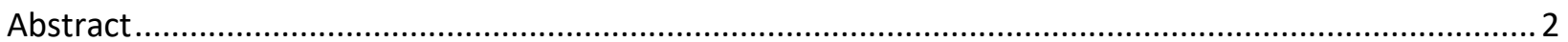

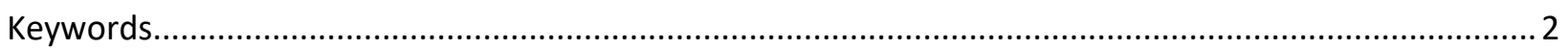

Genealogies of the Racial Project: It did not Start on 9/11 ............................................................. 4

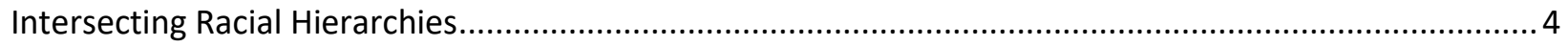

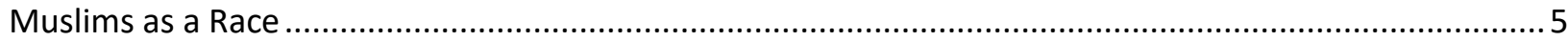

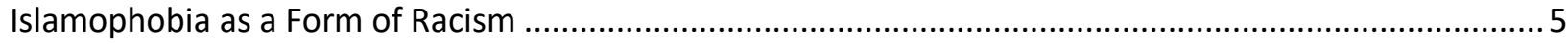

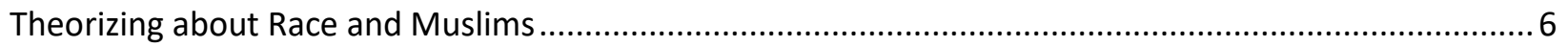

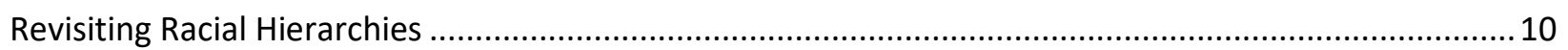

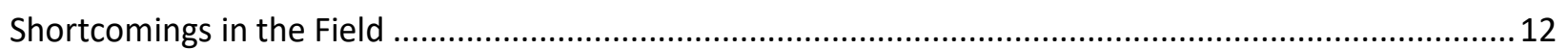

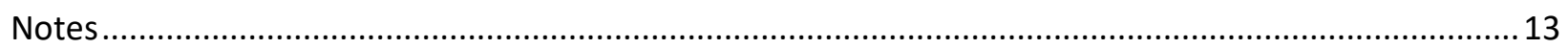

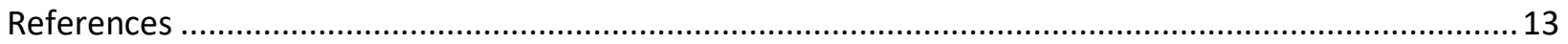




\title{
Review of Race Scholarship and the War on Terror
}

\author{
Louise Cainkar
}

Marquette University, Milwaukee, WI

Saher Selod

Simmons College, Boston, MA

\section{Abstract}

The 9/11 terrorist attacks and heavy-handed state and popular response to them stimulated increased scholarship on American Muslims. In the social sciences, this work has focused mainly on Arabs and South Asians, and more recently on African Americans. The majority of this scholarship has not engaged race theory in a comprehensive or intersectional manner. The authors provide an overview of the work on Muslims over the past 15 years and argue that the Muslim experience needs to be situated within race scholarship. The authors further show that September 11 did not create racialized Muslims, Arabs, or South Asians. Rather, the authors highlight a preexisting, racializing war on terror and a more complex history of these groups with race both globally and domestically. Islamophobia is a popular term used to talk about Muslim encounters with discrimination, but the concept lacks a clear understanding of race and structural racism. Newer frameworks have emerged situating Muslim experiences within race scholarship. The authors conclude with a call to scholars to embark on studies that fill major gaps in this emerging field of study-such as intersectional approaches that incorporate gender, communities of belonging, black Muslim experiences, class, and sexuality-and to remain conscious of the global dimensions of this racial project.

\section{Keywords}

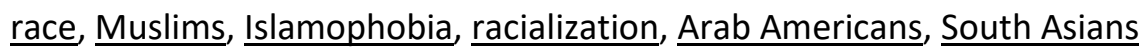

Scholarship on those racialized by the representations, narratives, policies, and practices associated with the "war on terror" covers a wide range of substantive issues analyzed from an array of disciplinary and theoretical perspectives. If, as Omi and Winant (2015:105) state, "race is a way of making up people," then the racialized group of bodies constituting the collectivity of "terror suspects," "potential terrorists," and "terror threats" is large and varied: the opposite of its assumed uniformity. Careful scholarship requires a disciplinary crosscutting and nimble movement across a body of literature that crosses ethnic, racial, and religious boundaries. Good sociological research on U.S. Muslims as racialized subjects should be contextualized by scholarship on the racial experiences of U.S. Arabs, South Asians, and blacks, its largest subgroups. Muslims, Arabs, and South Asians have been racialized by the same racial project that ideologically deploys an essentialized narrative of "terror threat" working in tandem 
with state and civil society macro and micro practices of control. At the same time, the war on terror's racial project intersects with the historic U.S. racial project of white supremacy so that groups may experience it somewhat differently, additionally highlighting the critical importance of intersectional approaches.

To demonstrate our assertion that policies and practices informed by the ideological premises and representations of the war on terror encompass a broad range of persons, consider the following. The Trump administration's "Muslim ban," based on geography, also restricts the movement of Christian Arabs and Iranian Jews. Hate crimes driven by animus toward Muslims find Hindus and Sikhs as their victims (Southern Poverty Law Center). Anti-Arab racism is often directed at Iranians, who are not Arabs (Maghbouleh 2017). New York Police Department anti-terror spying operations map their spatial areas of interest using demographic profiles of Arabs, South Asians, and black Muslims (Bayoumi 2015; Rana 2016). The U.S. government's post-9/11 special registration program required citizens of 24 Arab, North African, and South Asian countries to submit to security interviews and face potential removal (Cainkar $\underline{2003}, \underline{2009}$ ). Secretive post-9/11 detentions, deportations, and voluntary departures involved Arabs and South Asians of varying religions, but mainly Muslims (Cainkar 2009; Cole 2003; Hagopian 2004). Black Somali Muslim youth were under the microscope of the Obama administration's anti-terror Countering Violent Extremism program (Nguyen 2016). White Muslim women who wear hijab are shown to lose white privilege (Galonnier 2015; Moosavi 2015). The transnational affiliations of all of these persons are treated by the government with suspicion (Bassiouni 1974; Howell and Shryock 2003; Kibria 2011). Indeed, anthropologist Zareena Grewal (2014) noted that cues relying not only on phenotype but also on "names, turbans, ceremonial knives, veils, and flash cards" have extended punishment beyond these groups to Latinos and Native Americans, arguing that "the racial category of Middle Eastern-, Arab-, or Muslim-looking people is imprecise, too fluid, too wide a net" (p. 298). Finally, critical race scholar ChanMalik (2011:9) noted that "the taint of Islam" easily crosses racial boundaries. The "racialized and gendered archetypes of Islam as either brown-skinned Arab or South Asian male terrorists, or brownskinned women in hijab" just as easily vilified white "American Taliban" John Walker Lindh, black American sniper suspect John Allen Muhammad, and Chinese American U.S. Army Muslim chaplain James Yee.

Scholars agree that the "war on terror" names this racial project (Bayoumi 2015; Omi and Winant 2015; Rana 2011), yet many scholars are unaware that this project began decades before $9 / 11$, before it had an official name (Cainkar forthcoming; Perry 2014). Arabs, South Asians, and Muslims were racialized prior to the attacks, not because of them (Cainkar 2009; Grewal 2014; Naber 2000). This racial project differs in purpose and scope from the project that launched white supremacy at the birth of the nation. It is conducted in the interest of U.S. global hegemony and what Rana (2016) called the "terror-industrial complex": a web of domestic and global security agencies, surveillance mechanisms, police forces, militaries, and contractors. Indeed, there are many ways in which global U.S. actions and terrorism are co-constitutive (Mamdani 2004). Because this racial project is grounded in the policies of empire (Ho 2004), and because its emergence was layered upon earlier racial and gender projects, its racialized subjects are positioned and identified in multiple intersecting ways, including by geography, skin color, clothing, gender, religion, and beliefs. There is no single racial naming of this made-up group of people, except that they are understood by the state and the public to be threats: terrorists and potential terrorists. ${ }^{1}$ 


\section{Genealogies of the Racial Project: It did not Start on 9/11}

Although it is common for scholars to set 9/11 as the starting date of the racialization of Arabs, Muslims, and South Asians, that time is more accurately seen as a deepening and expanding of war on terror processes already in place. Grewal (2014) noted, "Muslim Americans are long familiar with being treated with suspicion; however political pressures and hyperscrutiny of their communities, whether from government, the media, their neighbors, or even researchers, intensified dramatically after September 11 " (p. 9). Pointing to a "broader history and culture that supports anti-Muslim, anti-Arab, and antiMiddle East sentiments," Perry (2014:75) argued that "post 9/11 violence was informed by a long, if largely unknown history [emphasis added] of defamation, violence, and non-violent discrimination in the US" against Arabs and Muslims. Cainkar (2009) argued that the negative treatment of Arabs and Muslims in the United States after 9/11 "was caused not by the attacks themselves but by pre-existing social constructions that configured them as people who would readily conduct and approve of such attacks" (p. 2). The 9/11 attacks are no more explanatory for ensuing events than the Pearl Harbor attacks are for explaining Japanese internment. Except by recognizing that an essentialized racial construct of suspicion and threat was already firmly in place, there is simply no way to understand the 96,000 suspicious persons tips that were generated within one week of the attacks, the nationwide hate crimes, and the collective guilt imposed on all of these groups for the attacks. Decades before 9/11, Arabs and Muslims had been characterized in American culture by ideological narratives casting them as monolithically barbaric and violent groups of misogynist men and abused women (Suleiman 1999), narratives informed by colonial Orientalism (Kumar 2012; McAlister 2001; Said 1978) and more longstanding white European Christian animosity toward Islam (Grosfoguel 2012; Shohat 2012). Race scholars would benefit from familiarizing themselves with the body of scholarship on this largely unknown history because it provides insights into how groups considered marginally white can change race (Cainkar 2006, forthcoming; Jamal and Naber 2008), the racialized feeling of being invisible (Saliba 1999; Samhan 1999; Naber 2000), hegemonies in the academy (Cainkar forthcoming), the formation of an Arab American panethnicity as a product of racialization (Suleiman 1999), and the fluidity of racial ideologies and representations that cast ever widening nets of subjects. Most important, recognizing the real starting date of the "war on terror" permits us to stop blaming 19 brown-skinned bodies for the racialization of brown and Muslim-looking people, a blame-the-victim scenario; instead it affirms that this is but another project of global white supremacy.

\section{Intersecting Racial Hierarchies}

The widening net of the war on terror project brings groups with distinct racial histories into the mix of its subjects, highlighting the importance of contextualizing their experiences intersectionally. Arab Americans are officially classified as white by the U.S. government and historically benefited from some of the perquisites of marginal whiteness, even though at times their right to naturalize as whites was contested (Gulatieri 2009). Partly because of this historical classification and the upward economic mobility it permitted, in addition to concerted practices of exclusion, their racialization and experiences of subjection to government surveillance and removals, popular hate crimes, negative media representations, and widespread stereotyping (signaling high visibility) beginning in the late 1960s went unrecognized by outsiders, including by many race scholars (Cainkar 2006, forthcoming). - This status of "oppressed yet invisible" drove Arab American advocacy for a census category beginning in the mid1980s (Kayyali 2013; Samhan 1999). Historic affiliation with whiteness explains why the leadership of this panethnic campaign sought an ethnic rather than racial category. 
South Asians, on the other hand, experienced both inclusion and exclusion from whiteness in the early twentieth century when their attempts to become naturalized citizens were challenged. Haney Lopez (2006) documented several legal cases where Asian Indians were determined to be white by the courts, which had used "common knowledge" and "scientific evidence" to argue that Asian Indians were white and not white. The 1923 Supreme Court case United States vs. Bhagat Singh Thind, a Sikh from India, decided that Hindus were not white, revealing how religion has been used to racialize immigrants. Because of this ruling and the Asia Barred Zone, mass migration of South Asians to the United States was barred for years until the passage of the Immigration and Nationality Act of 1965. After that time, highly educated South Asian professionals dominated immigration and were able to access economic opportunities, some social mobility, and affluent suburban neighborhoods. Nonetheless, many scholars have documented South Asian experiences with discrimination which have only been compounded by the war on terror (Dhingra 2007; Kibria 1998, 2011; Purkayastha 2005).

African American Muslims also have a long history of repression, state harassment, and surveillance, layered on top of their status as black Americans (Curtis 2002, 2006; Daulatzai 2012; Marable and Aidi 2009). Abdul Khabeer's (2017) ethnography of Muslim American hip-hop situates black Muslims within black American history and spaces, articulating the ways American Muslim lives play out within other existing racial hierarchies. Her discussion of U.S. South Asian/Arab hegemony over the performance of Islam alerts us to the ways that groups lying between black and white seek to climb into whiteness through anti-Blackness (Prashad 2000; Roediger 2007).

\section{Muslims as a Race}

Making a case for the Muslim experience in the United States as racial has not been an easy task. Prior to $9 / 11$ much of the sociological scholarship was not in race and ethnicity but found in studies on religion, immigration, political sociology, or from an international perspective. These fields have been notorious for undertheorizing race and ethnicity. There have been some instances in which religion and race scholarship have intersected, such as studies on the black church (Emerson and Smith 2001; Gilkes 2000; McRoberts 2003; Williams 2003). Black liberation theology and the role of the black church in the civil rights movement made this connection between race and religion impossible to ignore (Morris 1984). However, this connection has been less obvious to scholars studying the Muslim experience within the sociology of religion. They have not engaged with their racial experiences but instead focused on the ways Muslims in the United States have integrated into mainstream society through civic engagement (Kniss and Numrich 2007) or on how second-generation Muslim youth participate in creating a new American Islam that differs from their immigrant parents (Williams 2011). Absent from this research are the ways Muslim immigrants have historically been racialized, the black Muslim experience, and the structural barriers that prevent Muslims from experiencing complete "assimilation." The spike in prejudice, discrimination, and profiling that Muslims in the United States faced after the 9/11 attacks created a space for scholars to rethink the U.S. Muslim experience as racial and for scholars to revisit the long history of Muslim encounters with racism tied to European colonialism and the Muslim presence in Iberia (Grosfoguel and Mielants 2006; Rana 2007).

\section{Islamophobia as a Form of Racism}

One of the most popular concepts used to describe discrimination against Muslims is Islamophobia. Garner and Selod (2015) identified a boon of scholarship using the term Islamophobia after the terrorist 
attacks on 9/11. Islamophobia is not a new term. Dating back a century, the word emerged from European colonial encounters with Muslim populations and was used to describe European anger and hatred toward Islam as the enemy of Western civilization (Bravo López 2011). This longer history of Islamophobia is often overlooked in scholarship; instead, recent scholarship relies on the definition provided in a report titled "Islamophobia: A Challenge for Us All" by Runnymede Trust (1997), a race equality think tank in Britain. The report defines Islamophobia as an "unfounded hostility toward Islam," that results in "unfair discrimination against Muslim individuals and communities" (Shryock 2010). Widespread use of this term created a controversy among scholars studying race and racism. Writing shortly after the report's release, some scholars argued that the term did not accurately explain the racial discrimination faced by Muslims because it relied too heavily on religious discrimination (Halliday 1999; Meer and Modood 2009).

More recent scholarship contends that Islamophobia should be seen as a form of racism (Grosfoguel and Mielants 2006; Meer 2013; Garner and Selod 2015; Love 2017; Maghbouleh 2017). ${ }^{3}$ Maghbouleh (2017) found the term Islamophobia problematic because it conflates all Muslim experiences with racism, making them seem uniform, and does not allow a more nuanced understanding of how racial and ethnic groups have different histories of racialization in the United States, as we have argued. Similarly, Kibria (2011) argued that it flattens a Muslim identity and ignores the nuances of Muslim experiences with racism that are uniquely tied to ethnicity, race, nationality, gender, and sexuality. In response to criticism, the Runnymede Trust (2016) revised its definition of Islamophobia in an article titled "Islamophobia-20 Years On, Still a Challenge for Us All," acknowledging that "Islamophobia is a form of anti-Muslim racism."

Although some scholars pushed back against using the term Islamophobia, others argued that in order to use it, it must be reconceptualized as a form of racism. To accomplish this, scholars have had to redefine what race means. Tyrer (2013) stated, "the search for phenotypical raciality as a means of determining racism is, of course, a red herring, for race is socially constructed" (p. 40). The reduction of race to biological differences enables the invisibility of Muslim raciality. Tyrer showed how the misidentification of Sikhs as Muslims makes visible the way that Muslim bodies are indeed racialized. Erik Love's (2017) book Islamophobia and Racism in America traces the history of Islamophobia in the United States and demonstrates the ways in which it is a form of structural racism. Watch lists and surveillance programs that target Muslims are proof of how the state participates in racially profiling them. One of Love's most important findings is that South Asian, Arab, and Muslim organizations downplay racism in their efforts to participate in civil rights advocacy. By using a color-blind approach to combat Islamophobia, they deny that Islamophobia is a form of racism (Love 2017).

\section{Theorizing about Race and Muslims}

The first body of sociological scholarship to capture and define what Muslims were experiencing after 9/11 began appearing in 2003, with large-scale studies published in 2009. Louise Cainkar's (2009) book Homeland Insecurity: The Arab American and Muslim American Experience after 9/11 provided an indepth analysis of the laws and policies implemented in the war on terror and a qualitative exploration of how they affected the everyday experiences of Arab Muslims living in the metropolitan Chicago area. The heightened anti-Arab/Muslim racism that 9/11 brought about was not a new phenomenon but one that had been invisible for many reasons, including the de jure racial classification of Arabs as white in the United States. The Detroit Arab American Study Team (2009) published Citizenship and Crisis, the 
results of a 2003 Detroit-area study that oversampled Arab Americans. Among other things, the study found chronic tensions of exclusion and inclusion, that Arab Americans are viewed as essentially foreign, and that Arab Muslims feel more alienated from the mainstream than Arab Christians. In Backlash 9/11: Middle Eastern and Muslim Americans Respond, Anny Bakalian and Medhi Bozorgmehr (2009) chronicled the ways in which Arab, South Asian, and Muslim ethnic organizations that had been in existence in the United States for decades, such as the Islamic Society of North America, responded to the anti-Muslim and anti-Arab hate crimes that followed the attacks on September 11. Lori Peek (2011) wrote Behind the Backlash: Muslims Americans after 9/11, based on interviews with Muslims in New York City weeks after the terrorist attacks, documenting the initial backlash they experienced. Peek used disaster research theory to understand the hostility and isolation Muslim Americans encountered. Although these texts have been highly influential for sociologists studying Muslim populations, many of them are not centered on the racial dynamics of anti-Muslim sentiments.

Some two thirds of Muslims in the United States, immigrants and their offspring, have attracted the attention of immigration scholars. Richard Alba and Nancy Foner's (2015) book Strangers No More: Immigration and the Challenges of Integration in North America and Western Europe is an example of scholarship that situates Islam as a barrier to integration and assimilation in Europe and the United States. In their book, Alba and Foner report on how Muslim immigrants in Britain fare in terms of job opportunities, educational access, and residential segregation, comparing them with African Americans. Yet they treat religion and race as if they are two separate phenomena, arguing that both create barriers to complete integration into mainstream American and British societies. Racialization provides an alternative perspective to that of immigration scholars. Treitler (2015) argued that an assimilationist approach to immigration systematically ignores the racialized structural barriers that prevent some immigrants from faring well in the United States. Treitler convincingly argued that reliance on integration as a determination of success upholds the existing racial order because it ignores the racialized social structures that prevent any form of assimilation. Treitler proposed racialization as an alternative frame to understand immigrant experiences:

Thus, scholars of racialization do not expect the character of the system to be neutral with regard to the ethnic and racial groups it forms; the purpose of race is to engender hierarchies that create inequality. Thus, it is not possible that a group's own action is solely responsible for the political, social, and economic outcomes with which it has to live. (p. 156)

We note that the last sentence echoes our critique of scholarship that suggests that the events of 9/11 alone caused the racialization of Arabs, Muslims, and South Asians. Nazli Kibria's (2011) book Muslims in Motion provides an alternative to an assimilationist framework as she examines the intersections of ethnicity, race, and nationality in how Muslims from Bangladesh experience migration and acceptance in the United States, Britain, the Middle East, and Malaysia. Exploring structural barriers in a global context, Kibria does not flatten Muslims as a monolithic group but contextualizes the experiences of Bangladeshi Muslims in different countries, uncovering their nuanced experiences in each context.

To date, the majority of scholarship that has framed the Muslim experience as racial is found in anthropology, women's and gender studies, American studies, and English. Junaid Rana (2011) examined how Pakistani transnational laborers were caught up in a global racialized system after 9/11. He historicized the racialization of the Muslim body and revealed how in a global racial system, Muslim bodies are not just racialized as a "biological body but also as a cultural and social entity constructed 
within a number of discursive regimes, including those of terrorism, fundamentalism, patriarchy, sexism and labor migration" (p. 28). Naber (2006) interrogated the war on terror as a racial project, providing an understanding of how an Arab identity is racialized. Like Rana, she uncovered the ways in which race, religion, class, gender, sexuality and citizenship intersect to produce racialized Arabs. Jasbir Puar's (2007) book Terrorist Assemblages: Homonationalism in Queer Times examines how nationalism, sexuality, race, and ethnicity work together to produce homonationalism, which incorporates some queer bodies into the national identity through their participation in racializing Muslims, Sikhs, and Arabs as others who do not belong and who also threaten white queer bodies. Moustafa Bayoumi's $(2008,2015)$ work chronicles how religion is racialized via policies and laws passed after $9 / 11$. He argued that the National Security Entry-Exit Registration System (NSEERS) is a perfect example of a policy that targeted Muslims, racialized as a threat to national security. Under NSEERS, noncitizen men over the age of 16 from 25 countries were required to register with authorities upon entry to the United States, at which point they were fingerprinted, interrogated, and photographed. Those already in the United States were also required to do so. Of the 25 countries on this list, 24 were Muslim majority, with North Korea being the exception to the rule. Sunaina Maira $(2009,2016)$ has written extensively on how Muslim immigrant youth are racialized, hypersurveilled, and unable to access full citizenship as a result of American investment in empire building in the Middle East. All of these studies identify race as a major component and employ an intersectional approach to understanding the Muslim experience in the war on terror.

Many of these studies from outside of sociology use Omi and Winant's (1994) concepts of racial formation and racial projects to explain how South Asian and Arab identities are racialized, showing the theory's reach outside of the discipline. According to Omi and Winant (2015), "race is about marking human bodies" and is "nebulous, indeterminate, and flexible" (p. 112). Scholars thus recognize that both phenotype and cultural and religious markers are used to distinguish bodies associated with terror threat and that these markers are gendered and highly flawed. A focus on phenotypes is apparent in Peek's (2003) article on Muslim students in post 9/11 New York, in which the key role played by the ocular is evident: "Thousands of Arabs, Muslims, Sikhs, and individuals who appeared to be of Middle Eastern descent became the victims of discrimination, harassment, racial and religious profiling, and verbal and physical assault" (p. 271). "Middle Eastern" is an actionable social construct that produces images of a certain "swarthy" phenotype (brown skin, black hair, chiseled facial features); its geography has expanded in size to include much of the Muslim world as the war on terror produces an imaginary "single geopolitical mass" (Rana 2011:5). Yet, as noted earlier, in addition to phenotype, cultural markers such as names, turbans, and veils, also provoke a racial response.

In the third edition of their book, Omi and Winant (2015) defined racialization as "the extension of racial meaning to a previously racially unclassified relationship, social practice or group" (p. 111). This definition provided the much-needed language in race theory to conceptually explain how religion can acquire racial meaning, allowing scholars to explore Muslim experiences with racism (Garner and Selod 2015; Moosavi 2015; Selod and Embrick 2013). Their definition of race is limiting, however, in that it rests on physical dimensions alone: "Race is a concept, a representation or signification of identity that refers to different types of human bodies, to the perceived corporeal and phenotypic markers of difference and the meanings and social practices that are ascribed to these differences" (Omi and Winant 2015:111). Race is a socially constructed concept that has been narrowly defined as signification of difference on the basis of the physical, typically referring to skin tone, hair texture, and so on. But 
racism is not only experienced by those who have a darker pigmentation or some evidence of corporeal distinction. It extends to cultural attributes as well as physical ones. Garner and Selod (2015) contended that to understand how Muslim experiences are racial, scholars must rethink what attributes are racialized and what characterizes one's race.

Cultural aspects of racism need to be recognized in order to understand how the Muslim experience is racialized. Perpetuating cultural racism, whereby cultural differences are blamed for one's marginalization, is one of the ways Muslims have been racialized epistemologically (Said 1978, 1981, 1997). Lack of attention to how Muslims have acquired new racialized identities via cultural traits within a changing sociohistorical racialized social system (Bonilla-Silva 2002) has aided in keeping the racialized experiences of Muslims invisible. In a racialized social system, everyone has racial experiences, so attention should be paid to how South Asian, black, and Arab ethnic and racial identities impart onto one's bodies differential experiences because of racism. The process of racialization entails ascribing sets of characteristics viewed as inherent to members of a group because of their physical or cultural traits. In the case of Muslims, their religious identity provokes racism and ignites racialized experiences. These are not limited to skin tone or pigmentation but include myriad attributes, including cultural traits such as language, clothing, and religious practices. The characteristics thus emerge as "racial" as an outcome of the process. Racialization provides the language needed to discuss both newer forms of racism that are not only based on skin color and older forms (Garner and Selod 2015:4). By using a framework of racialization that is not limited to pigmentation, we are able to provide a more comprehensive and nuanced understanding of how Muslims experience racism on the basis of cultural traits that are conflated with biology.

For example, the hijab, a religious signifier worn by Muslim women, ascribes certain characteristics to those who wear it, regardless of skin tone, resulting in racial encounters and experiences (Cainkar 2009; Perry 2014; Selod 2015). For individuals who are racially classified as white, wearing the hijab darkens their appearance, resulting in their inability to claim their whiteness (Moosavi 2015). A Muslim name can also act as a racializing agent. It inscribes onto bodies associations with terror, misogyny and barbarism. Selod $(2016,2018)$ showed how South Asian and Arab men are subjected to racialized surveillance at airports because their names match similar ones on Transportation Security Administration airport lists. These men were stopped, searched, and interrogated about their travels

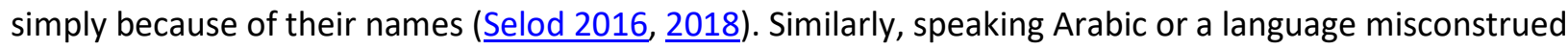
as Arabic may subject one to racial encounters, such as being removed from an airplane, because it marks one as belonging to a part of the world that is represented as a threat to Americans. It thus becomes important to recognize how racial experiences and racism are not only incited by skin color, but also by the intersection of cultural attributes that acquire racial meaning.

Theories of race that permit examination of multiple attributes, besides just the biological, prove extremely helpful in explaining the misidentification of individuals as belonging to a perceived racial group. Zopf's (2017) comparative study of Egyptian Christians and Muslims describes a "layered process in which race, ethnicity, national origin, and religion combine in unique ways in defining Arabs and Middle Easterners not only as brown and foreign but also more specifically as anti-American Muslim terrorists" (even if they are not Muslim). Referring to the ways in which brown-skinned ethnoracial groups are simultaneously "homogenized and differentiated" in the U.S., Zopf (2017) concluded that Arab and Middle Eastern Americans represent a "different" kind of brown, "racialized as anti-American whose allegiance to the United States is not possible because of religion." Naber (2006) argued that 
cultural racism, phenotypic racism, and nation-based racism work together to draw a "wide range of subject positions ... into war on terror policies," including Arab Christians, Iranian Jews, and South Asians of any faith, "illustrating that dominant discourses on Islam and Muslims are not only malleable and fluid but arbitrary fictional and imaginary at best" (p. 277). Rana (2016:120) concluded that the category Muslim is "a system of race deemed not to be a race" and is given meaning not only as a faithbased association but as an expansive racialized figure encompassing many nationalities, cultures, and religions. Unpacking how cultural attributes are racialized allows a nuanced explanation of the miscategorization of some groups as enemies of the state in the war on terror.

The idea that cultural attributes are being racialized is not a new concept but is one we argue should get more attention in race scholarship. Eduardo Bonilla-Silva (2003) identified cultural racism as one of the frames of color-blind racism. Cultural racism occurs when a group's culture acquires racial meaning and is used to justify its inferiority (Bonilla-Silva 2015). Aranda and Rebollo-Gil (2004) coined the term ethnoracism, which they defined as the racialization of ethnicity, to explain how other Americans, specifically Puerto Ricans, have been racialized. "Race in 20th-century America is not limited to phenotype; the social construction of race involves ethnic and global dimensions such as national origin, culture, language, religion, the historical relationship between colonial powers and their political subjects, and race" (Aranda and Rebollo-Gil 2004: 913). Attention to culture in race theory is needed for an incorporation of the Muslim experience into race scholarship. In sum, scholarship reveals that the racial subject formed by the war on terror is marked in multiple ways, not only by phenotype but by a range of symbols understood to signify the threatening other, including cultural and religious markers, places of origin, names, languages, and curvilinear written scripts attached to the east. The Muslim experience allows us to examine how racial meaning through the racialization of cultural attributes, could help explain how other groups are racialized. Thus, the impact of this scholarship extends beyond an examination of just Muslims because it has forced scholars to rethink concepts like race and racialization so that the scope of race scholarship is not limited.

\section{Revisiting Racial Hierarchies}

Studies on race should never be done or fixed as racial categories are not static but change over time. Eduardo Bonilla-Silva (2004) contended that the United States is moving toward a triracial society in his Latin Americanization thesis. He argued there is a new American racial hierarchy, which consists of three main racial categories: whites, honorary whites, and collective black (Bonilla-Silva 2004, 2010). According to this thesis, the influx of newer immigrants to the United States after the passage of the Immigration and Nationality Act of 1965 has resulted in a racial terrain that looks more similar to Latin America. This newer racial hierarchy allows discussion of how groups move up and down a racial ladder and how whiteness maintains itself at the top. Work by Prashad (2000) and Love (2017) suggests that some racially excluded Arabs, South Asians, and Muslims may see color-blind racism as their route to upward mobility.

Cultural racism and the racialization paradigm allow us to consider how to racially classify Muslims. Where do Muslims fit on the racial hierarchy? Are Muslims becoming a central racialized focus, creating a new racial category? Or is it the conflation of Muslims and Arabs that results in those marked as Muslim being treated as if they are Arab. Or, as Cainkar (forthcoming) argues, narratives and representations of Muslims and "Middle Easterners" are so conflated that a wide range of undifferentiated groups are understood and treated as racialized terror threats. Love (2017) wrote in his 
study of organized challenges to Islamophobia, "There is no doubt that a socially constructed racial category exists, and has existed for a long time," noting acronyms used by scholars to define this broad mix of people racialized as terror threats, including AMEMSA (Arabs, Middle Easterners, Muslims, and South Asians), and SWANA (South West Asians and North Africans). The latter acronym was adopted by the University of California system after advocacy by a collectivity of constituent groups (Maghbouleh 2017). Love argued that these terms are both cumbersome and limited and do not sufficiently encompass everyone targeted by the racial category. He added that when most Americans use the term Muslim they are probably referring indiscriminately to all of these persons (to which he adds Sikhs), yet he argued that the term Muslim is too vague and homogenizing; it ignores multiple subjectivities, positionalities, and sites of belonging. Kibria (2011:3-4) argued that the explosion of interest in Muslims in the wake of 9/11 and its aftermath has produced a "flattened" understanding of Muslims, replete with one-dimensional views and homogenizing. She demonstrated that attention to place of origin remains important because group lives unfold on a matrix of networks, institutions, histories and ties that "stretch across societies of origin and reception." Chan-Malik (2011:8-9) described Muslims as a group composed of "dizzying racial, ethnic, class, and generational diversity" and an "expansive range of Islamic belief and practice."

Love (2017) resolved his quest for a term to define the subjects of his study by opting for "Middle Eastern," arguing that it evokes a racial image that best captures his range of subjects. Yet he also referred to it as an identity, despite scant evidence that many people identify with the term. Indeed, the term has a negative history; it was deployed in the war on terror racial project when a new construct was needed to expand existing anti-Arab racism to Muslims following the Iranian revolution and the rise of Islamist challenges to U.S. global hegemony (Cainkar 2006, forthcoming). As a construct built on an artificial place and riddled with negative representations, it is an unlikely source of subjective identity. Furthermore, "Middle Eastern" is too limited to describe the broader group of subjects and bodies that we have demonstrated are entangled in this racial project. Would the impending, but now postponed, Middle East North Africa census category have produced a sense of affiliation with the term, as has been demonstrated for other groups (Omi and Winant 2015)? ? Such an outcome was certainly not the intent of advocates, who in addition to countering invisibility wanted to provide researchers with better data on matters such as health and well-being, educational attainment, and income (Ajrouch and Antonucci 2018). We argue that identities racialized as terror threats intersect with other existing racialized identities to produce varying outcomes depending upon these positionalities. Selod (2018) argued that this intersection produces shifts on the racial hierarchy. Thus, a religious identity becomes a marker of race and results in the loss of social privileges, such as a South Asian physician may have had prior to the post-9/11 intensification of the racial project. Now living under state surveillance, Pakistani Muslims in the United States are subjected to more scrutiny because of the institutionalized discrimination that targets Muslim bodies. Similarly, Arabs who may pass as whites are racialized because of their presumed religious identity.

We conclude from this review of the complexities of naming the wide group of people caught in the war on terror racial project that scholars working in this field (which lacks a concise name) will advance our understanding of racialization at work and race theory by resisting homogenization and grounding their research in specificities of gender, national origin, religion, social class, multiple racial positionings, and multiple sites of belonging, including the communities they are linked to both domestic and abroad. The case of Arabs, South Asians, and Muslims and race pushes us to continue to theorize about race by 
taking into account the global, domestic, and local contexts within which racial meanings are created in order to understand the material and social motivations that underlie these constructions. At the same time, we must avoid the pitfalls of limiting race to physical components of the body. To truly understand newer racialized experiences, race scholars should start rethinking the language we rely on to talk about racism in the United States and find creative and nuanced ways to talk about race in a multiethnic, multiracial, multinational and multireligious society. Omi and Winant (2015) stated that race is not a static concept but a fluid one and that racial projects should be understood contextually within their sociopolitical era. In the current sociopolitical era, the racialization of Muslims has been institutionalized by a war on terror that is being fought globally as well as domestically. Muslim racialized experiences should be conceptualized in a global context as well as within the American racial hierarchy. This review calls for the broadening of race scholarship in general.

\section{Shortcomings in the Field}

Sociological scholarship on race and Muslims lacks an incorporation of the black Muslim experience, even though Africans brought as slaves were the first large group of Muslims in United States. Scholars in the field of religious studies have done far more robust work on the intersection of blackness and being Muslim (Curtis 2002, 2006; Jackson 2005; Karim 2008; McCloud 2014), recently augmented by anthropologist Abdul Khabeer's (2017)Muslim Cool. Scholarship on Islamophobia operates under the premise that Muslims are South Asian or Arab, rendering black Muslims and their unique histories with racism invisible. We simply do not know, from a sociological perspective, how Muslim and black identities intersect in the war on terror. Are black Muslims surveilled both as blacks and as Muslims, and how do their experiences differ from South Asian and Arab Muslims? We reiterate our call for scholars examining Muslim experiences to ground their research in multiple intersecting axes of race, ethnicity, gender, and communities of belonging and to recognize that a racialized religious identity does not replace a racialized ethnoracial one but rather intersects with it. Scholarship on Muslims and race needs to provide nuanced intersectional analyses in order to avoid the pitfalls of creating a false narrative that Muslims are a monolithic group.

Second, our research designs and our research questions should not be abstracted from the global realities of the war on terror, not only because they have meaning to members of these groups but also because absent structural changes in macro U.S. global policies, we can expect few changes in domestic policies of surveillance, policing, expulsion, and banning or micro practices of discrimination and violence. Abdul Khabeer (2017:196) argued that neoliberal belonging requires the "domestication of racial politics," situating Muslims "within a multiracial and multifaith US American tradition of social activism" and narrowing their concerns away from their international and transnational frameworks of belonging. Scholars working without a global frame of reference risk facilitating such a neoliberal project. We find that this risk runs higher when taking into account the more recent domestication of the anti-Muslim racial project, as examined by Bail (2015) in Terrified: How Anti-Muslim Fringe

Organizations Became Mainstream. Bail reveals how fringe organizations, such as Brigitte Gabriele's ACT for America!, have been successful in influencing the mainstream narrative around Muslims as more than terror threats and shaping public opinion of this population. Gaining steam in 2006, concurrent with Barack Obama's intent to run for the presidency, this expansion and elaboration of the anti-Muslim racial project, marked by anti-Sharia legislative campaigns and nationwide protests against mosques, framed Muslims as threats to American culture and democracy (Ali et al. 2011; Grewal 2014; Bayoumi 
2015; Earle 2015). Thanks in part to these fringe groups, energized by Trump campaign allies, popularly organized domestic anti-Muslim activities have increased in recent years (Southern Poverty Law Center), provoking in turn increased scholarly interest. Studying these events, their genesis and impacts, are important research activities, yet unless they are situated in a global context, they risk creating another version of color-blind racism, one that endorses solving a problem by explicitly ignoring its root structural causes.

Finally, gender and sexuality are undertheorized in scholarship on Arabs, South Asians, and Muslims. Scholars should pay attention to how these racialized identities are experienced in unique ways on the basis of gender and sexuality. The sociology of race and ethnicity often reduces racial experiences to those of men, forcing us to step outside of our discipline to find the language to explain these intersections. It is time for the sociology of race and ethnicity to move beyond limited explanations of race and incorporate the nuances of culture, clothing, gender, sexuality, class, nationality, and religion.

\section{Notes}

1. Efforts to fine-tune discipline and surveillance programs by determining predictors of terrorism continue without success (see Desmarais et al. 2017). Yet government programs deploying such notions have been in place across the country (see Nguyen 2016). NYU Law School's Brennan Center for Justice has compiled resources on Countering Violent Extremism, a program that stigmatizes Muslims on the basis of "flawed theories of terrorist radicalization which lead to unnecessary fear, discrimination, and unjustified reporting to law enforcement."

2. See Cainkar (2018) for elaboration of other factors contributing to Arab American racialization that went unnoticed by scholars.

3. See also "Islamophobia Is Racism: A Resource for Teaching \& Learning about Anti-Muslim Racism in the United States" (https://islamophobiaisracism.wordpress.com).

4. On January 26, 2018, the Census Bureau announced that the 2020 census would not include a Middle Eastern North African category.

\section{References}

Abdul Khabeer, Suad. 2017. Muslim Cool: Race, Religion, and Hip Hop in the United States. New York: NYU Press.

Ajrouch, Kristine J., and Toni C. Antonucci. 2018. "Social Relations and Health: Comparing 'Invisible' Arab Americans to Blacks and Whites." Society and Mental Health 8(1):84-92.

Alba, Richard, and Nancy Foner. 2015. Strangers No More: Immigration and the Challenges of Integration in North America and Western Europe. Princeton, NJ: Princeton University Press.

Ali, Wajahat, Eli Clifton, Matthew Duss, Lee Fang, Scott Keyes, and Faiz Shakir. 2011. Fear, Inc. Washington, DC: Center for American Progress.

Aranda, Elizabeth M., and Guillermo Rebollo-Gil. 2004. "Ethnoracism and the 'Sandwiched' Minorities." American Behavioral Scientist 47(7): 910-27.

Bail, Christopher A. 2015. Terrified: How Anti-Muslim Fringe Organizations Became Mainstream. Princeton, NJ: Princeton University Press.

Bakalian, Anny, and Medhi Bozorgmehr. 2009. Backlash 9/11: Middle Eastern and Muslim Americans Respond. Berkeley: University of California Press. 
Bassiouni, M. Cherif, ed. 1974. The Civil Rights of Arab-Americans: The Special Measures. North Dartmouth, MA: Arab-American University Graduates

Bayoumi, Moustafa. 2008. How Does It Feel to Be a Problem? New York: Penguin.

Bayoumi, Moustafa 2015. This Muslim American Life: Dispatches from the War on Terror. New York: NYU Press.

Bonilla-Silva, Eduardo. 2002. "We Are All Americans! The Latin Americanization of Racial Stratification in the USA." Race and Society 5(1):3-16.

Bonilla-Silva, Eduardo. 2003. Racism without Racists: Color-blind Racism and the Persistence of Racial Inequality in the United States. Lanham, MD: Rowman \& Littlefield

Bonilla-Silva, Eduardo. 2004. "From Bi-racial to Tri-racial: Towards a New System of Racial Stratification in the USA." Ethnic and Racial Studies 27(6):931-50.

Bonilla-Silva, Eduardo. 2010. Racism without Racists: Color-blind Racism and the Persistence of Racial Inequality in the United States. 3rd ed. Lanham, MD: Rowman \& Littlefield.

Bonilla-Silva, Eduardo. 2015. "More Than Prejudice: Restatement, Reflections, and New Directions in Critical Race Theory." Sociology of Race and Ethnicity 1(1):73-87.

Bravo López, Fernando. 2011. "Towards a Definition of Islamophobia: Approximations of the Early Twentieth Century." Ethnic and Racial Studies 34(4):556-73.

Cainkar, Louise. 2003. "A Fervor for Muslims: Special Registration." Journal of Islamic Law and Culture 7(2):73-101.

Cainkar, Louise. 2006. "The Social Construction of Difference and the Arab American Experience." Journal of American Ethnic History 25(2):243-78.

Cainkar, Louise. Forthcoming. "Fluid Terror Threat: A Genealogy of the Racialization of Arab, Muslim, and South Asian Americans." Amerasia Journal 44(1).

Cainkar, Louise A. 2009. Homeland Insecurity: The Arab American and Muslim American Experience after 9/11. New York: Russell Sage.

Chan-Malik, Sylvia. 2011. "'Common Cause': On the Black-immigrant Debate and Constructing the Muslim American." Journal of Race, Ethnicity, and Religion 2(8):1-39

Cole, David . 2003. Enemy Aliens. New York: New Press.

Curtis, E. Edward . 2002. Islam in Black America: Identity, Liberation, and Difference in African-American Islamic Thought. Albany, NY: State University of New York Press.

Curtis, E. Edward . 2006. Black Muslim Religion in the Nation of Islam, 1960-1975. Chapel Hill, NC: University of North Carolina Press.

Daulatzai, Sohail . 2012. Black Star, Crescent Moon: The Muslim International and Black Freedom Beyond America. Minneapolis: University of Minnesota Press.

Desmarais, S. L., Simons-Rudolph, J., Brugh, C. S., Schilling, E., Hoggan, C. 2017. "The State of Scientific Knowledge Regarding Factors Associated with Terrorism." Journal of Threat Assessment and Management 4(4):180-209.

Detroit Arab American Study Team . 2009. Citizenship and Crisis. New York: Russell Sage.

Dhingra, Pawan . 2007. Managing Multicultural Lives. Stanford, CA: Stanford University Press.

Earle, Chris . 2015. "Good Muslims, Bad Muslims, and the Nation: The 'Ground Zero Mosque' and the Problem with Tolerance." Communication and Critical Cultural Studies 12(2):121-38. 
Emerson, Michael, Smith, Christian. 2001. Divided by Faith: Evangelical Religion and the Problem of Race in America. New York: Oxford University Press.

Galonnier, Juliette . 2015. "When 'White Devils' Join the Deen: White Americans Converts to Islam and the Experience of Non-normative Whiteness." Retrieved February 15, 2018 (http://www.sciencespo.fr/osc/sites/sciencespo.fr.osc/files/nd 2015 01.pdf)

Garner, Steve, Selod, Saher. 2015. "The Racialization of Muslims: Empirical Studies of Islamophobia." Critical Sociology 41(1):9-19.

Gilkes, Cheryl Townsend. 2000. If It Wasn't for the Women ...: Black Women's Experience and Womanist Culture in Church and Community. Maryknoll, NY: Orbis.

Grewal, Zareena. 2014. Islam Is a Foreign Country. New York: NYU Press.

Grosfoguel, Ramon. 2012. "The Multiple Faces of Islamophobia." Islamophobia Studies Journal 1(1):933.

Grosfoguel, Ramon, and Eric Mielants. 2006. "The Long-Durée Entanglement between Islamophobia and Racism in the Modern/Colonial Capitalist/Patriarchal World-system: An Introduction." Human Architecture 5(1):1

Gualtieri, Sarah. 2009. Between Arab and White: Race and Ethnicity in the Early Syrian American Diaspora. Berkeley, CA: University of California Press.

Hagopian, Elaine, ed. 2004.Civil Rights in Peril. Chicago: Haymarket Books.

Halliday, Fred. 1999. "Islamophobia' Reconsidered." Ethnic and Racial Studies 22(5):892-902.

Haney Lopez, lan. 2006. White by Law. New York: NYU Press.

Ho, Engseng. 2004. "Empires through Diasporic Eyes: A View from the Other Boat." Comparative Study of Society and History 46(1):210-46.

Howell, Sally, and Andrew Shryock. 2003. "Cracking Down on Diaspora: Arab Detroit and America's 'War on Terror.'" Retrieved February 15, 2018

(http://citeseerx.ist.psu.edu/viewdoc/download?doi=10.1.1.452.9413\&rep=rep1\&type=pdf).

Jackson, Sherman. 2005. Islam and the Blackamerican: Looking toward the Third Resurrection. New York: Oxford University Press on Demand.

Jamal, A. Amaney, and Nadine Naber, eds. 2008. Race and Arab Americans before and after 9/11: From Invisible Citizens to Visible Subjects. Syracuse, NY: Syracuse University Press.

Karim, Jamillah. 2008. American Muslim Women: Negotiating Race, Class, and Gender within the Ummah. New York: NYU Press.

Kayyali, Randa. 2013. "US Census Classifications and Arab Americans: Contestations and Definitions of Identity Markers." Journal of Ethnic and Migration Studies 39(8):1299-1318.

Kibria, Nazli. 1998. "The Contested Meanings of 'Asian American': Racial Dilemmas in the Contemporary US." Ethnic and Racial Studies 21(5):939-58.

Kibria, Nazli. 2011. Muslims in Motion: Islam and National Identity in the Bangladeshi Diaspora. New Brunswick, NJ: Rutgers University Press.

Kniss, Fred, and Paul D. Numrich. 2007. Sacred Assemblies and Civic Engagement: How Religion Matters for America's Newest Immigrants. New Brunswick, NJ: Rutgers University Press.

Kumar, Deepa. 2012. Islamophobia and the Politics of Empire. Chicago: Haymarket Books.

Love, Erik. 2017. Islamophobia and Racism in America. New York: NYU Press.

Maghbouleh, Neda. 2017. The Limits of Whiteness. Stanford, CA: Stanford University Press.

Maira, Sunaina. 2009. Missing: Youth, Citizenship, and Empire after 9/11. Durham, NC: Duke University Press. 
Maira, Sunaina. 2016. The 9/11 Generation: Youth, Rights, and Solidarity in the War on Terror. New York: NYU Press.

Mamdani, Mahmood. 2004. Good Muslim, Bad Muslim: America, the Cold War, and the Roots of Terror. New York: Pantheon.

Marable, Manning, and Hisham Aidi. 2009. Black Routes to Islam. New York: Palgrave-Macmillan.

McAlister, Melanie. 2001. Epic Encounters: Culture, Media, and U.S. Interests in the Middle East Since 1945. Berkeley, CA: University of California Press.

McCloud, Aminah . 2014. African American Islam. New York: Routledge.

McRoberts, Omar . 2005. Streets of Glory: Church and Community in a Black Urban Neighborhood. Chicago: University of Chicago Press.

Meer, Nasar . 2013. "Racialization and Religion: Race, Culture and Difference in the Study of Antisemitism and Islamophobia." Ethnic and Racial Studies 36(3):385-98.

Meer, Nasar, Modood, Tariq. 2009. "Refutations of Racism in the 'Muslim question.'” Patterns of Prejudice 43(3-4):335-54.

Moosavi, Leon . 2015. "The Racialization of Muslim Converts in Britain and Their Experiences of Islamophobia." Critical Sociology 41(1):41-56.

Morris, Aldon . 1984. The Origins of the Civil Rights Movement: Black Communities Organizing for Change. New York: Simon \& Schuster.

Naber, Nadine . 2000. "Ambiguous Insiders: An Investigation of Arab American Invisibility." Ethnic and Racial Studies 23(1):37-61.

Naber, Nadine . 2006. "The Rules of Forced Engagement: Race, Gender, and the Culture of Fear among Arab Immigrants in San Francisco Post-9/11." Cultural Dynamics 18(3):235-67.

Nguyen, Nicole . 2016. A Curriculum of Fear: Homeland Security in US Public Schools. Minneapolis: University of Minnesota Press.

Omi, Michael, Winant, Howard. 1994. Racial Formation in the United States from the 1960s to the 1990s. New York: Routledge.

Omi, Michael, Winant, Howard. 2015. Racial Formation in the United States. New York: Routledge.

Peek, Lori A. 2011. Behind the Backlash: Muslims Americans after 9/11. Philadelphia, PA: Temple University Press.

Peek, Lori . 2003. "Reactions and Response: Muslim Students' Experiences on New York City Campuses Post-9/11." Journal of Muslim Minority Affairs 23(2):273-85.

Perry, Barbara . 2014. "Gendered Islamophobia: Hate Crime against Muslim Women." Social Identities 20(1):74-89.

Prashad, Vijay . 2000. The Karma of Brown Folk. Minneapolis: University of Minnesota Press.

Puar, Jasbir . 2007. Terrorist Assemblages: Homonationalism in Queer Times. Durham, NC: Duke University Press.

Purkayastha, Bandana . 2005. Negotiating Ethnicity. New Brunswick, NJ: Rutgers University Press.

Rana, Junaid . 2007. "The Story of Islamophobia." Souls 9(2):148-61.

Rana, Junaid Akram . 2011. Terrifying Muslims: Race and Labor in the South Asian Diaspora. Durham, NC: Duke University Press.

Rana, Junaid Akram . 2016. "The Racial Infrastructure of the Terror-industrial Complex." Social Text 34(4):111-38.

Roediger, David R. 2007. The Wages of Whiteness: Race and the Making of the American Working Class. London: Verso. 
Runnymede Trust . 1997. "Islamophobia: A Challenge for Us All." London: Runnymede Trust.

Runnymede Trust . 2016. "Islamophobia-20 Years On, Still a Challenge for Us All." Retrieved February 15, 2018 (https://www.runnymedetrust.org/blog/islamophobia-20-years-on-still-a-challengefor-us-all).

Said, Edward. 1978. Orientalism. New York: Vintage.

Said, Edward . 1981. Covering Islam: How the Media and the Experts Determine How We See the Rest of the World. New York: Pantheon.

Said, Edward . 1997. Covering Islam: How the Media and the Experts Determine How We See the Rest of the World. New York: Vintage.

Saliba, Therese . 1999. "Resisting Invisibility." Pp. 304-19 in Arabs in America: Building a New Future. Philadelphia, PA: Temple University Press.

Samhan, Helen Hatab . 1999. "Not Quite White: Race Classification and the Arab-American Experience." Pp. 209-26 in Arabs in America: Building a New Future, edited by Suleiman, M. W. Philadelphia, PA: Temple University Press.

Selod, Saher . 2015. "Citizenship Denied: The Racialization of Muslim American Men and Women Post9/11." Critical Sociology 41(1):77-95.

Selod, Saher . 2016. "Criminalization of Muslim American Men in the United States." In The Immigrant Other: Lived Experiences in a Transnational World, edited by Furman, R., Ackerman, A. New York: Columbia University Press.

Selod, Saher . 2018. Forever Suspect: Racialized Surveillance of Muslim Americans in the War on Terror. New Brunswick, NJ: Rutgers University Press.

Selod, Saher, Embrick, David. 2013. "Racialization and Muslims: Situating the Muslim Experience in Race Scholarship." Sociology Compass 7(8):644-55.

Shohat, Ella . 2012. "The Moorish Atlantic: Orientalism/Occidentalism between the Middle East and the Americas." In Between the Middle East and the Americas: The Cultural Politics of Diaspora, edited by Alsultany, E., Shohat, E. Ann Arbor, MI: University of Michigan Press.

Shryock, Andrew . 2010. Islamophobia/Islamophilia. Bloomington, IN: Indiana University Press.

Southern Poverty Law Center . N.d. Hatewatch. Retrieved February 16, 2018 (https://www.splcenter.org/hatewatch).

Suleiman, Michael W , ed. 1999. Arabs in America: Building a New Future. Philadelphia, PA: Temple University Press.

Treitler, Vilna Bashi . 2015. "Social Agency and White Supremacy in Immigration Studies." Sociology of Race and Ethnicity 1(1):153-65.

Tyrer, David . 2013. The Politics of Islamophobia: Race, Power and Fantasy. London: Pluto.

Williams, Johnny Eric . 2003. African-American Religion and the Civil Rights Movement in Arkansas. Oxford: University Press of Mississippi.

Williams, Rhys . 2011. "Association for the Sociology of Religion Presidential Address: Creating an American Islam: Thoughts on Religion, Identity, and Place." Sociology of Religion 72(2):127-53.

Zopf, Bradley . 2017. "A Different Kind of Brown: Arabs and Middle Easterners as Anti-American Muslims." Sociology of Race and Ethnicity. Retrieved February 15, 2018 (http://journals.sagepub.com/doi/abs/10.1177/2332649217706089?journalCode=srea). 